The Cryosphere Discuss., https://doi.org/10.5194/tc-2019-52

Manuscript under review for journal The Cryosphere

Discussion started: 27 March 2019

(c) Author(s) 2019. CC BY 4.0 License.

\title{
Improved characterization of alpine permafrost through structurally constrained inversion of refraction seismic data
}

\author{
Matthias Steiner ${ }^{1,2}$, Florian M. Wagner ${ }^{3}$, Adrian Flores Orozco ${ }^{1}$ \\ ${ }^{1}$ Geophysics Research Division, Department of Geodesy and Geoinformation, TU-Wien, Vienna, 1040, Austria \\ 5 '2Institute of Applied Geology, Department of Civil Engineering and Natural Hazards, University of Natural \\ Resources and Life Sciences, Vienna, 1190, Austria \\ ${ }^{3}$ Geophysics Section, Institute of Geosciences and Meteorology, University of Bonn, Bonn, 53115, Germany \\ Correspondence to: Matthias Steiner (matthias.steiner@geo.tuwien.ac.at)
}

\footnotetext{
Abstract. Geophysical methods are widely used to investigate the influence of climate change on alpine permafrost. Methods sensitive to the electrical properties, such as electrical resistivity tomography (ERT), are the most popular in permafrost investigations. However, the necessity to have a good galvanic contact between the electrodes and the ground in order to inject high current densities is a main limitation of ERT. Several studies have demonstrated the potential of refraction seismic tomography (RST) to overcome the limitations of ERT and to monitor permafrost processes. Seismic methods are sensitive to contrasts in the seismic velocities of unfrozen and frozen media and thus, RST has been successfully applied to monitor seasonal variations in the active layer. However, uncertainties in the resolved models, such as underestimated seismic velocities, and the associated interpretation errors are seldom addressed. To fill this gap, in this study we review existing literature regarding refraction seismic investigations in alpine permafrost permitting to develop conceptual models illustrating different subsurface conditions associated to seasonal variations. We use these models to conduct a careful numerical study aiming at a better understanding of the reconstruction capabilities of standard and constrained RST approaches. Our results demonstrate, that the incorporation of structural constraints in the inversion and the usage of constrained initial models help to better resolve the geometry and the velocity structure of the true models. Moreover, we present the successful application of this extended constrained approach for the inversion of refraction seismic data acquired at Hoher Sonnblick (Austria) by incorporating complementary information obtained from the modelling of ground-penetrating radar (GPR) signatures. In conclusion, our study shows the potential of an extended constrained RST to improve the reconstruction of subsurface units and the associated seismic velocities in a permafrost environment, permitting to reduce the uncertainties in the interpretation of the imaging results.
} 
The Cryosphere Discuss., https://doi.org/10.5194/tc-2019-52

Manuscript under review for journal The Cryosphere

Discussion started: 27 March 2019

(c) Author(s) 2019. CC BY 4.0 License.

\section{Introduction}

Permafrost denotes subsurface areas with temperatures remaining at or below $0{ }^{\circ} \mathrm{C}$ for at least two consecutive years (Harris et al., 1988) and thus, is particularly vulnerable to climate change (Haeberli et al., 2010). The Alps are especially sensitive to increasing air temperatures and decreasing solid precipitation in mountainous regions

5 (Gobiet et al., 2014) causing the degradation of alpine permafrost (Noetzli and Gruber, 2009; Keiler et al., 2010). Understanding permafrost degradation is critical to prevent associated geohazards, such as rockfalls (Phillips et al. 2017; Ravanel et al., 2017) and rock avalanches (Deline et al., 2013; Coe et al., 2018), as well as floods caused by the impact of rock masses into lakes (Haeberli et al., 2016). Furthermore, slope instabilities due to retreating permafrost pose a threat to infrastructure in alpine regions (Harris et al., 2009; Keuschnig et al., 2017).

10 Thus, delineating the spatial distribution of alpine permafrost as well as the quantification of temporal changes are essential for the evaluation of climate change in natural environments, the assessment of present and future hazards (Haeberli et al., 2016) and the planning of engineering projects in alpine regions (Harris et al., 2009; Bommer et al., 2010). Direct methods in permafrost investigations refer to surface measurements using ground surface temperature, or bottom temperature of the snow cover; while temperature sensors placed in boreholes

15 (Biskaborn et al., 2015) can be used to gain information on the subsurface thermal conditions (e.g., PERMOS, 2016). However, the spatial resolution of these methods is limited to the locations of the sampling points. Moreover, due to difficult site accessibility for deep drilling and financial reasons, increasing the number of measurement points in alpine regions is possible to a limited extent only. Hence, information with high spatiotemporal resolution is required for a better assessment of the influence of climate change.

20 Geophysical methods offer opportunities for permafrost investigations with high resolution, and in a noninvasive manner, complementing the thermal monitoring of permafrost evolution (Beniston et al., 2018). Methods sensitive to electrical properties are the most popular for permafrost investigations due to the contrasting electrical resistivity corresponding to lithological media (commonly related to moderate values), water (highly conductive) and ice (which is assumed to be an electrical insulator). Hence, electrical resistivity

25 tomography (ERT) and ground penetrating radar (GPR) are widely used in permafrost studies (Hinkel et al., 2001; Berthling et al., 2008; Hilbich et al., 2008; Krautblatter et al., 2010; Schöner et al., 2012a; Kneisel et al., 2014; Supper et al., 2014; Kellerer-Pirklbauer and Kaufmann, 2017; Rogger et al., 2017). The main limitation in ERT refers to the necessity of the electrodes to have a good galvanic contact with the ground (Hauck, 2013; Supper et al., 2014), as required to inject high current densities and warrant an adequate signal strength. This

30 could be especially challenging in winter periods, when the surface is covered by snow and ice (Hilbich et al., 2009). GPR overcomes the necessity of maintaining a galvanic contact to the ground; yet, the interpretation of 
The Cryosphere Discuss., https://doi.org/10.5194/tc-2019-52

Manuscript under review for journal The Cryosphere

Discussion started: 27 March 2019

(c) Author(s) 2019. CC BY 4.0 License.

GPR data is subjective and qualitative. Moreover, high scattering of the electromagnetic waves in highly fractured media negatively affects the signal-to-noise ratio and the interpretation of the radargrams.

Several studies have investigated the applicability of the refraction seismic tomography (RST) method to monitor permafrost processes such as seasonal variations in the thickness of the active layer (e.g., Hilbich, 2010;

5 Rogger et al., 2017) and to overcome the limitations of ERT (Hilbich, 2010; Hauck et al., 2011; Draebing and Krautblatter, 2012). For a detailed review of the application of refraction seismic in permafrost studies, we refer to Draebing (2016). The nonuniqueness of the solution of the inverse problem underlying the RST requires the combination of different methods to minimize the uncertainties in the interpretation. For the interpretation of seismic signatures, the joint interpretation of geophysical and direct information (e.g., temperature) is commonly

10 applied in periglacial studies (e.g., Hauck et al., 2004; Hausmann et al., 2007; Schöner et al., 2012a; Stiegler et al., 2014). Here, the geometry of lithological units and the active layer, for instance, are defined based on the correlation between geophysical (e.g., seismic) and available ground truth data (e.g., temperature). However, differences in the accuracy and resolution of the geophysical models and the direct measurements can yield ambiguous interpretations (Doetsch et al., 2012). To overcome such problems, different strategies have been

15 suggested for data fusion: (i) statistical analysis and weighting of data obtained through different methods to compute a single model (e.g., Travelletti et al., 2009); (ii) the joint inversion of different data sets (Gallardo and Meju, 2003; Linde et al., 2008; Hellman et al., 2017; Ronczka et al., 2017); (iii) a constrained inversion incorporating structural information obtained through other geophysical or direct methods (e.g., Doetsch et al., 2012; Bergmann et al., 2016). Statistical analysis of the data may be affected by the same limitations as joint

20 interpretation, e.g. ambiguous results due to discrepancies in the underlying models (Doetsch et al, 2012; Hellmann et al., 2017). The petrophysical joint inversion may be limited due to the lack of proper petrophysical models linking subsurface properties and geophysical parameters. Further, the mutual structurally coupled joint inversion may not be applicable due to the inherent properties of the different data sets, such as resolution, signal-to-noise ratio and sensitivity to lithological structures. Accordingly, the incorporation of structural information from unconnected yet structurally similar data sets in the inversion offers clear advantages permitting to produce reliable geophysical models.

In this study, we review the existing literature regarding refraction seismic investigations in alpine permafrost. Based on information from laboratory and field studies, we design conceptual models illustrating different subsurface conditions associated to seasonal variations. Using these conceptual models, we perform a careful

30 numerical analysis to evaluate the reconstruction capabilities of different inversion approaches for refraction seismic data. In particular, we investigate the uncertainties in the resolved models, for example underestimated velocities, which can lead to wrong estimates of the ice content. For our analysis we use the open-source python 
The Cryosphere Discuss., https://doi.org/10.5194/tc-2019-52

Manuscript under review for journal The Cryosphere

Discussion started: 27 March 2019

(c) Author(s) 2019. CC BY 4.0 License.

library pyGIMLi (Geophysical Inversion and Modeling Library; Rücker et al., 2017), which permits to develop processing workflows reproducible for other seismic data acquired in permafrost environments. Moreover, we demonstrate an improved ability of the constrained inversion approach to reliably resolve for the actual geometry of the subsurface units and their corresponding seismic velocities. Furthermore, we present the application of constrained inversion approaches for the inversion of real seismic refraction data acquired at the summit of Hoher Sonnblick (Austria).

\section{Materials and Methods}

\subsection{Constrained inversion of RST data}

The inversion scheme minimizes the objective function $\phi=\phi_{d}+\lambda \phi_{m}$ with the regularization parameter $\lambda$ balancing the data misfit $\phi_{d}$ and the model roughness $\phi_{m}$ (Bergmann et al., 2014; Günther and Rücker, 2017). The data misfit is defined by

$\phi_{d}(\boldsymbol{m})=\left\|\mathbf{W}_{d}(\boldsymbol{d}-\boldsymbol{f}(\boldsymbol{m}))\right\|_{2}^{2}$

with $\boldsymbol{d}, \boldsymbol{f}$ and $\boldsymbol{m}$ denoting the data, the forward operator and the modeled data, respectively; further, the elements of $\mathbf{W}_{d}=\operatorname{diag}\left(1 / \epsilon_{i}\right)$ represent the error-derived data weights (Bergmann et al., 2014). Important data fit measures are the root-mean square (RMS) and the error-weighted chi-square fit (Günther et al., 2006)

$\chi^{2}=\frac{\phi_{d}}{N}$

where $\chi^{2}=1$ means a perfect fit (Günther and Rücker, 2017).

The inversion of geophysical data is an ill-posed problem with its solution being non-unique (e.g., Gallardo and Meju, 2003) and strongly dependent on the initial model used for the inversion. For the RST, initial models in which the seismic velocities increase gradually with depth in an isotropic manner are most commonly used. Such initial models are applicable in case of RST surveys in areas with no important topographic features. However, this approach can be strongly limited for alpine investigations, where topography might change dramatically. To better illustrate this problem, we present a gradient initial model applied on a rough topography (Fig. 1a). As the computation of the initial seismic velocities depends only on the general slope of the surface, it results in the generation of a physically implausible model. In this study, we compute initial seismic velocities based on the minimum distance to the surface by means of linear interpolation in order to create more realistic initial models. The initial model created for the rough topography example using the minimum-distance approach is shown in Fig. 1b, clearly demonstrating a physically plausible initial model. 
The Cryosphere Discuss., https://doi.org/10.5194/tc-2019-52

Manuscript under review for journal The Cryosphere

Discussion started: 27 March 2019

(c) Author(s) 2019. CC BY 4.0 License.
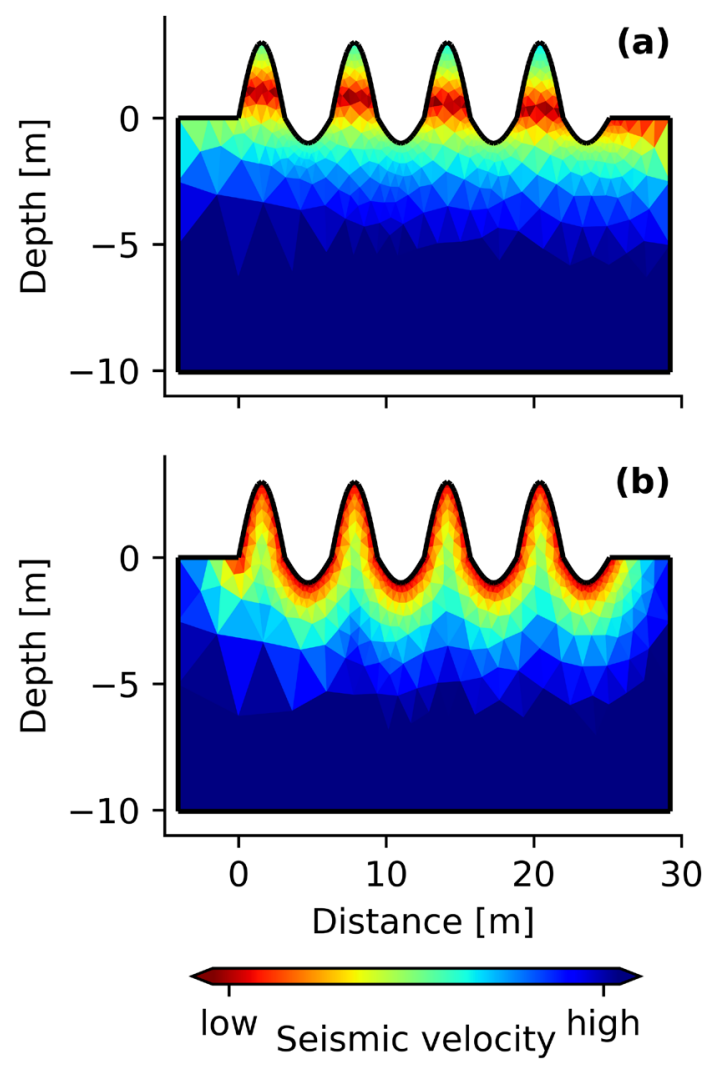

Figure. 1: Numerical example with rough topography illustrating (a) an initial model which considers the slope of the profile, and (b) the alternative approach taking into account the topography of the profile based on the minimum distance to the surface.

Besides the standard inversion using an initial model defined by an isotropic increase in the seismic velocity with depth, we propose the structurally constrained inversion of RST data. The second term of the objective function $\phi$, the model roughness $\phi_{m}$, is defined by

$\phi_{m}(\boldsymbol{m})=\left\|\mathbf{W}_{m} \mathbf{C} \mathbf{W}_{c}\left(\boldsymbol{m}-\boldsymbol{m}^{\mathbf{0}}\right)\right\|_{2}^{2}$

10 with $\boldsymbol{m}$ and $\boldsymbol{m}^{\mathbf{0}}$ representing the modeled data and the initial data, respectively (Bergmann et al., 2014). Further, $\mathbf{W}_{m}$ denotes the model control matrix, $\mathbf{W}_{c}$ the constraint weight matrix and $\mathbf{C}$ the constraint matrix that describes the degree of interdependence between neighboring model cells (Günther et al., 2006; Bergmann et al., 2014). Hence, the term $\mathbf{W}_{m} \mathbf{C} \mathbf{W}_{c}$ permits to incorporate structural information from unconnected yet structurally related data sets as constraints in the inversion of RST data. 
The Cryosphere Discuss., https://doi.org/10.5194/tc-2019-52

Manuscript under review for journal The Cryosphere

Discussion started: 27 March 2019

(c) Author(s) 2019. CC BY 4.0 License.
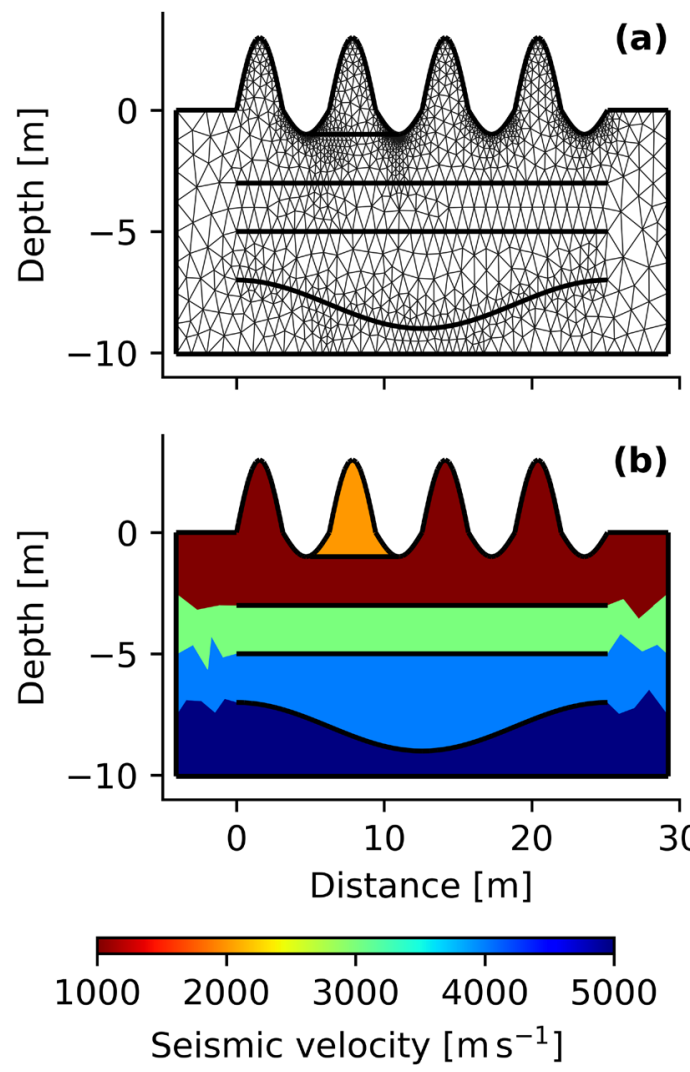

Figure 2: Illustrative examples of the incorporation of structural information. (a) Structural information used to incorporate constraints in a mesh. (b) Constant seismic velocities assigned to areas defined by the structural information.

We present here an implementation of the constrained inversion approach permitting (1) to incorporate an unlimited number of constraints in the inversion of RST data based on existing information (Fig. 2a) and (2) to create a constrained initial model by assigning constant seismic velocities to the structures defined by these constraints (Fig. 2b). The structural information from complementary sources are organized as coordinate lists

10 with an arbitrary number of elements permitting to model subsurface structures as shown in Fig. 2a. Based on the structural information for $\mathrm{N}$ subsurface interfaces, $\mathrm{N}+1$ seismic velocities have to be defined in order to generate a constrained initial model as presented in Fig. 2b. Considering the widely established term constrained inversion (Doetsch et al., 2012; Bergmann et al., 2014), we hereinafter use the term extended constrained inversion for an inversion based on structural constraints and constrained initial models. 
The Cryosphere Discuss., https://doi.org/10.5194/tc-2019-52

Manuscript under review for journal The Cryosphere

Discussion started: 27 March 2019

(c) Author(s) 2019. CC BY 4.0 License.

Numerical simulations and the inversion of synthetic and real RST data in this study were performed using the pyGIMLi framework (Rücker et al., 2017).

\subsection{Study area}

The study area is located on the south-facing debris-covered slope of the summit of Hoher Sonnblick shown in

5 Fig. 3. The Hoher Sonnblick (3106 m above sea level) is a mountain of the Goldberg Group in the Austrian Central Alps located at the border between the federal states of Salzburg and Carinthia. The Goldberg Group is characterized by a north-west striking gneiss zone ('Sonnblick-Gneisskern'; Exner, 1964) mainly consisting of granite gneiss with a predominant portion of potash feldspar (Exner, 1962). The observatory built on the summit in 1886 provides a long-term multi-elemental climate series. Air temperatures measured at the Sonnblick

10 Observatory between 1887 and 2010 show an increase in the mean annual air temperature (MAAT) of approximately $2{ }^{\circ} \mathrm{C}$ (Schöner et al., 2012b). The degradation of permafrost in the summit area required actions to ensure stability of the summit (Böhm et al., 2011), clearly reflecting the negative effects in the subsurface associated to the increase in MAAT. During the construction works, three boreholes, each with a depth of $20 \mathrm{~m}$, were drilled on the south-facing slope of the Hoher Sonnblick summit (Schöner et al., 2012a). Temperature

15 sensors installed in the boreholes provide data about the thermal state of the subsurface. However, due to the lack of data regarding the saturation of the subsurface materials, the temperature data are of limited use for the modeling and the interpretation of refraction seismic data.

\subsection{Collection of RST and GPR data at Hoher Sonnblick summit}

On 17 May 2017, we conducted RST and GPR measurements at Hoher Sonnblick summit to get information

20 about the subsurface conditions at the end of the freezing period. Both datasets were acquired along a profile stretching from the observatory building to the snowfield next to the glacier flanking the summit; the orientation of the profile is shown in Fig. 3 by the seismic shot points (yellow stars). Refraction seismic data were recorded using two units of the DMT Summit acquisition system permitting to use 48 geophones (corner frequency $30 \mathrm{~Hz}$ ). We deployed the geophones with a separation of $2 \mathrm{~m}$ and firmly installed those at the snow cover to

25 enhance the contact with the ground. A sledgehammer $(7.5 \mathrm{~kg})$ was used to generate elastic waves by performing hammer blows on a massive plastic plate. 
The Cryosphere Discuss., https://doi.org/10.5194/tc-2019-52

Manuscript under review for journal The Cryosphere

Discussion started: 27 March 2019

(c) Author(s) 2019. CC BY 4.0 License.

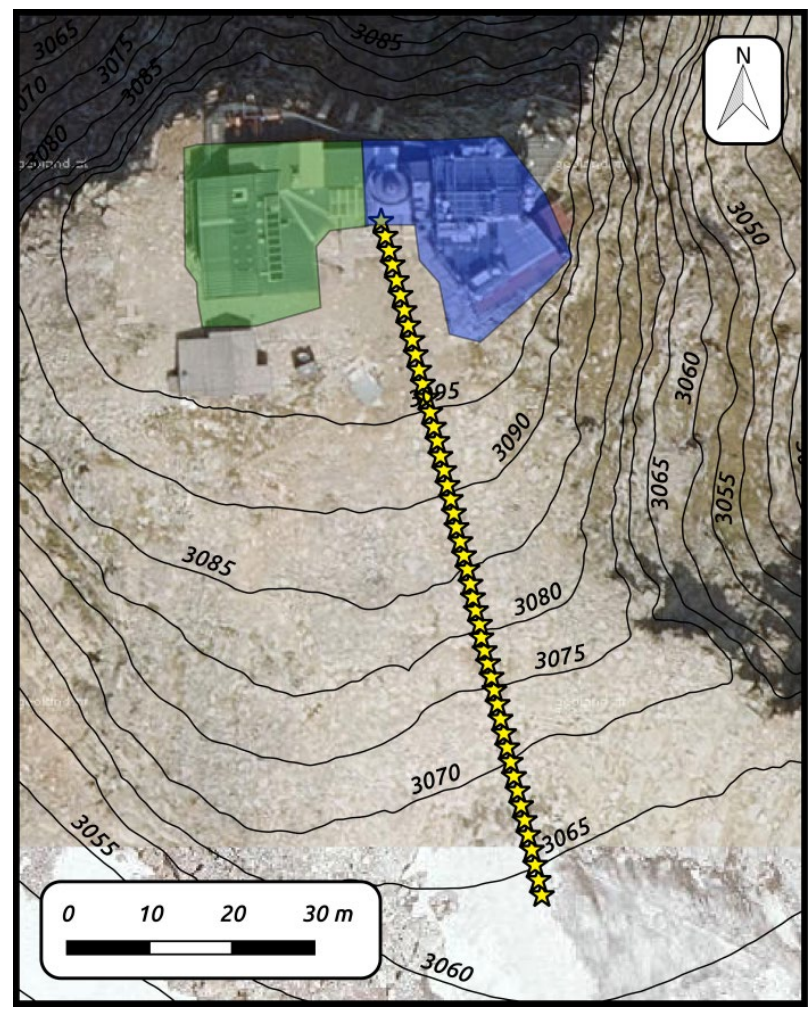

Figure 3: Detailed view of the study area with the Sonnblick Observatory (blue) and the hut of the Austrian Alpine Association (green) on top of the summit of Hoher Sonnblick. The location of the profile for the refraction seismic measurements conducted in May 2017 is indicated by the shot positions (yellow stars; shot positions correspond to geophone positions).

For the GPR data acquisition we used a SIR-3000 unit with a $200 \mathrm{MHz}$ antenna in common offset configuration. We acquired GPR data with high spatial resolution by slowly moving the antenna downhill and operating the SIR-3000 unit in the continuous recording mode. The modeling of the GPR data permitted the delineation of

10 subsurface structures and their corresponding electrical properties. To achieve this, numerous synthetic models were performed, in which the geometry and properties $(\sigma$ and $\varepsilon$, the electrical conductivity and dielectric constant respectively) of subsurface structure were varied to compute a synthetic radargram and compare it with the actually measured data (Maierhofer, 2018). The geometry and electrical properties found by the best-fit model were used to create a schematic representation of the subsurface conditions at the RST profile (as

15 presented in Fig. 4). Strong reflections at the interface between the snow cover and the ground surface permitted to determine the thickness of the snow layer ranging from approximately $2 \mathrm{~m}$ in the upper part of the profile to about $5 \mathrm{~m}$ at the bottom of the slope (next to the glacier). Below the snow cover, a layer consisting of debris and 
The Cryosphere Discuss., https://doi.org/10.5194/tc-2019-52

Manuscript under review for journal The Cryosphere

Discussion started: 27 March 2019

(c) Author(s) 2019. CC BY 4.0 License.

highly fractured rocks was resolved at a depth ranging between 3 and $5 \mathrm{~m}$, as presented in Fig. 4. The modeled GPR signatures revealed a layer of unresolved depth with electrical properties corresponding to frozen consolidated materials interpreted as the bedrock.

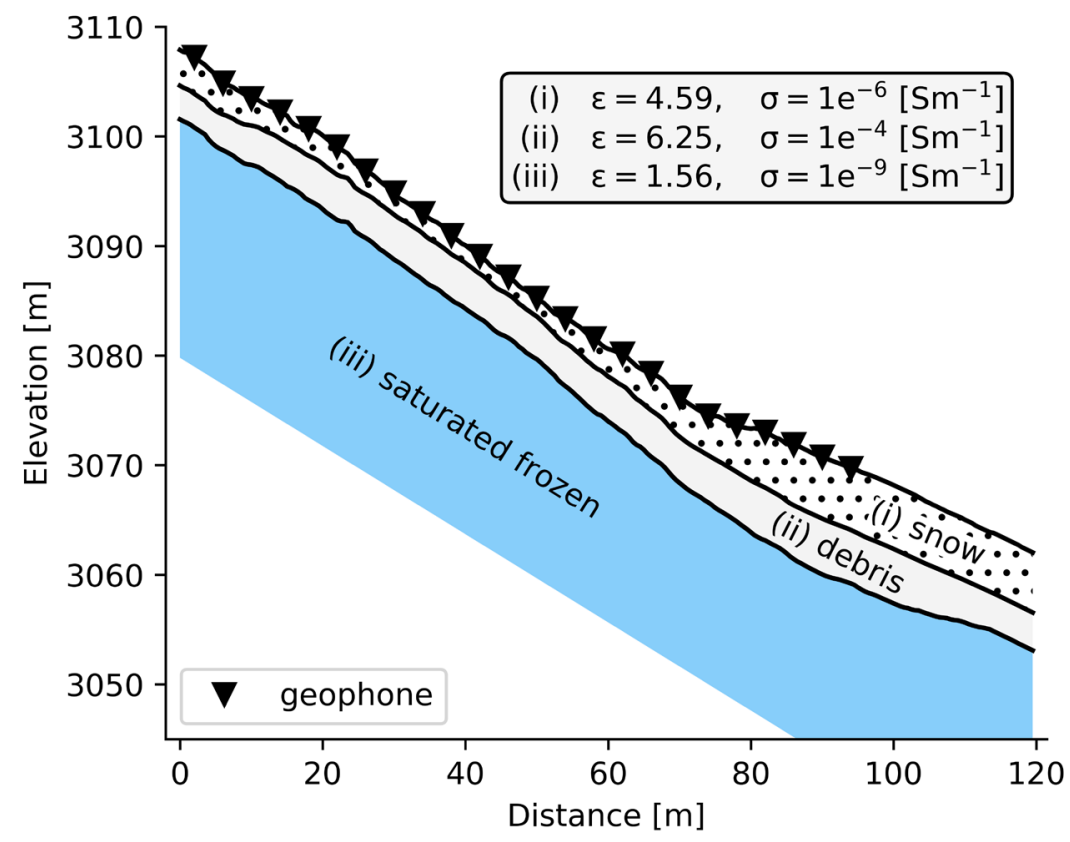

Figure 4: Bulk electrical properties (upper right text box) at the summit of Hoher Sonnblick as resolved from the modeling of GPR signatures. Such model is then used to define structural constraints for the inversion of the refraction seismic profile (black triangles illustrate the geophone positions).

\subsection{Conceptual subsurface models and their corresponding seismic velocities}

10 To perform our RST numerical study, we developed conceptual models corresponding to subsurface conditions expected at the slope of Hoher Sonnblick summit. These models are presented in Fig. 5 and consider (1) the known lithology, (2) the thermal state of the subsurface and seasonal variations, and (3) variations in the depth to the groundwater level (i.e., ice layer). As illustrated in Fig. 5, the lithology is mainly characterized by three layers: a shallow debris unit, an intermediate layer of fractured (i.e., weathered) granite gneiss, and the bedrock

15 at the bottom. To illustrate the thermal status, we use five different models, which can be divided in two sets corresponding to freezing $(\mathrm{F})$ and thawing $(\mathrm{T})$ periods.

Model F1 illustrates a fully saturated frozen slope at the end of winter; thus besides the lithology it is necessary to include an extra layer on the top corresponding to the snow cover. Accordingly, below the snow cover all 
The Cryosphere Discuss., https://doi.org/10.5194/tc-2019-52

Manuscript under review for journal The Cryosphere

Discussion started: 27 March 2019

(c) Author(s) 2019. CC BY 4.0 License.

voids are assumed to be filled with ice. In model F2, we assume lower water and ice contents at the end of the winter period. Hence, our model includes an additional interface within the debris cover to represent an upper unit with snow and air filled voids and an underlying unit consisting of ice-filled voids within the debris layer. The bottom layers are not changed between F1 and F2.

5 For the thawing period representing the subsurface at the end of the summer we do not consider the snow cover. Regarding the model T1, the debris is again divided in two layers representing air- and water-filled voids on the top and bottom respectively. Accordingly, fractures and cracks in the upper part of the fractured rock are assumed to be filled with water; whereas at the bottom of this layer we assume ice-filled fractures, to better represent the changes in thermal status. The bedrock represents the bottom layer, which we assume have the

10 same seismic properties as in models F1 and F2. Model T2 is similar to T1, yet we assume lower water saturation, i.e., a larger depth to groundwater table. Model T3 represents a deeper groundwater level, where the debris is fully unsaturated and the fractured material is then divided in two units: a water-filled unit on the top, and an ice-filled one at the bottom. Similar to the previous models the undermost layer represents the bedrock.

The velocities summarized in Table 1 are associated to the subsurface conditions at Hoher Sonnblick summit and

15 used in the conceptual models. Note, that these $V_{p}$ represent average values reported from laboratory and field investigations. As observed in Fig. 5, the most pronounced velocity contrasts are given at the lithological contacts; with a lower contrast associated to variations in the saturation, while phase changes from liquid to frozen water result in a comparatively small velocity contrast. The special scenario of a velocity reversal (commonly referred to as velocity inversion) is illustrated in model F2. Here, we assumed that the compaction of

20 the snow cover during the winter season results in higher seismic velocities than those of the underlying snowand air-filled debris cover. 
The Cryosphere Discuss., https://doi.org/10.5194/tc-2019-52

Manuscript under review for journal The Cryosphere

Discussion started: 27 March 2019

(c) Author(s) 2019. CC BY 4.0 License.

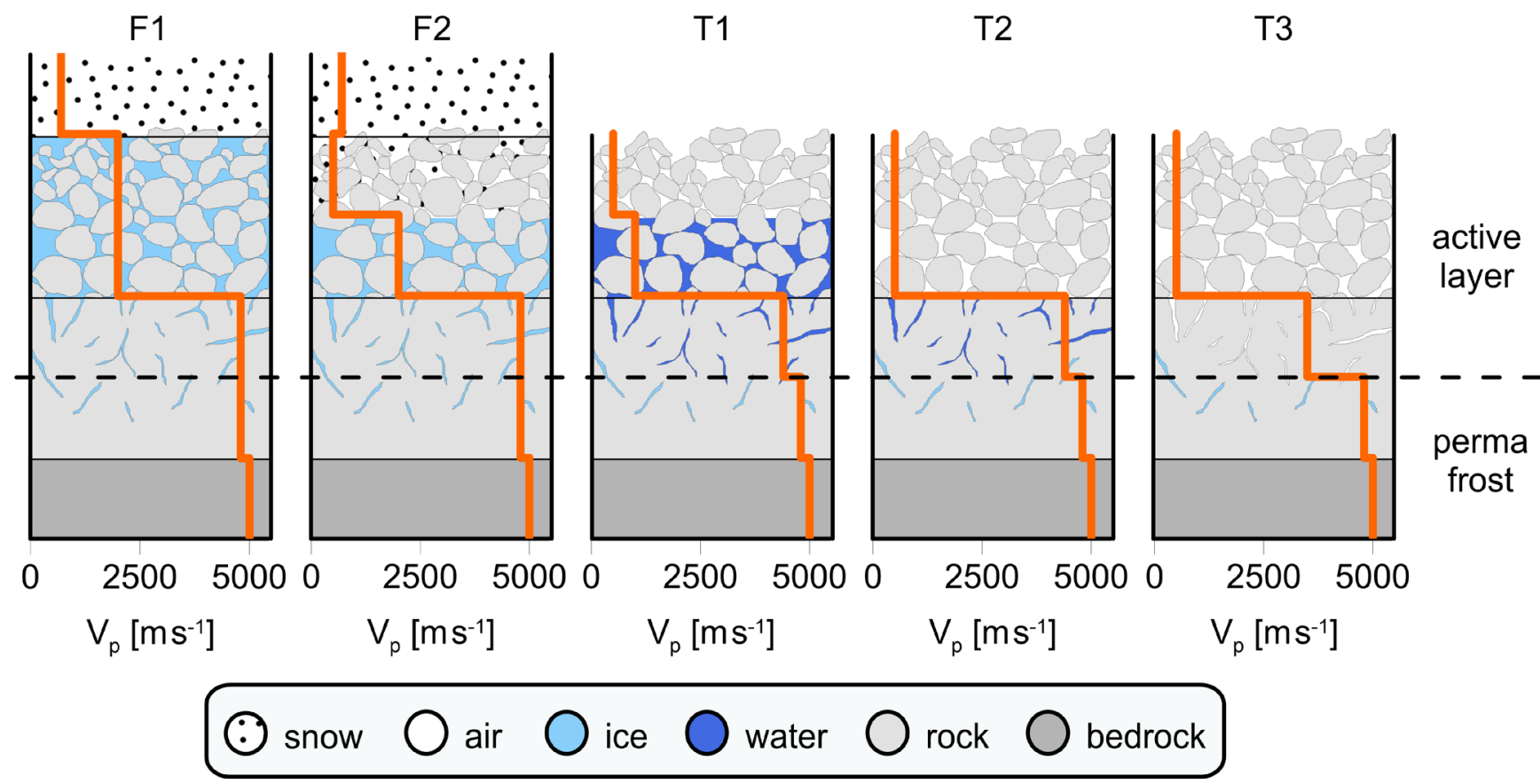

Figure 5: Conceptual models of the subsurface conditions at the summit of Hoher Sonnblick for different thermal states accompanying seasonal variations: at the end of winter including a snow cover (models F1 and F2), and at the end of summer (models T1, T2 and T3) for different ice-water saturation levels of the debris-covered slope. The corresponding seismic velocities are included as 1D velocity curves (orange).

Table 1. P-wave velocities $\left(V_{p}\right)$ of the conceptual models.

\begin{tabular}{lll}
\hline Layer composition & $\mathrm{V}_{\mathrm{p}}\left[\mathrm{ms}^{-1}\right]$ & References \\
\hline Snow & 700 & Reynolds, 2011; Marshall, 2011 \\
Debris + air & 500 & Draebing, 2016 \\
Debris + water & 1000 & Nur and Simmons, 1969; Draebing, 2016 \\
Debris + ice & 2000 & Schöner et al., 2012a \\
Fractured rock + air & 4000 & Nur and Simmons, 1969; Draebing, 2016 \\
Fractured rock + water & 4400 & Nur and Simmons, 1969; Draebing and Krautblatter, 2012 \\
Fractured rock + ice & 4800 & Draebing and Krautblatter, 2012 \\
Bedrock & 5000 & Schöner et al., 2012a \\
\hline
\end{tabular}


The Cryosphere Discuss., https://doi.org/10.5194/tc-2019-52

Manuscript under review for journal The Cryosphere

Discussion started: 27 March 2019

(c) Author(s) 2019. CC BY 4.0 License.

\section{Results and Discussion}

\subsection{Numerical study}

For the numerical study all synthetic data sets were subjected to Additive Gaussian White Noise (AGWN) of 0.5 ms. Figure 6 presents the numerical models and the computed inversion results as obtained following the three approaches investigated here: (a) standard inversion using a gradient initial model; (b) constrained inversion using a gradient initial model; and (c) extended constrained inversion using a constrained initial model (constant initial layer velocities). Additionally, we present in Fig. 7 the 1D-velocity curves resolved for the different models and inversion strategies. To this end, ten equidistantly spaced 1D-velocity curves were extracted along the flat part of the profile and averaged subsequently. To facilitate the evaluation of the different inversion approaches, the gray areas in Fig. 7 illustrate the velocity structure of the true models.

The velocity information obtained from the standard inversion using a gradient initial model are depicted as green lines. The true velocities are properly resolved in a depth of 3 to $5 \mathrm{~m}$ and in the deep-seated layers, while the estimated velocities within the intermediate layers are too low compared to the real model. Hence, our results demonstrate that the inversion with a gradient initial model yields underestimated seismic velocities for the given

15 synthetic data. Furthermore, in case of models F1 and F2, the default inversion approach is not able to detect the known layer boundaries. Although the green 1D velocity curves reflect the known velocity structure of models $\mathrm{T} 1, \mathrm{~T} 2$ and $\mathrm{T} 3$, the interface depths of the real models are not resolved accurately.

Applying the constrained inversion approach based on a gradient initial model yields the blue 1D velocity curves shown in Fig. 7. As expected, incorporating structural constraints permits to resolve the layer boundaries and to 20 obtain good estimates of the interface depths, although the associated velocity contrasts are not estimated correctly. With regard to the estimated velocities, the performance of the constrained inversion is similar to the standard inversion approach. Especially in the near surface the results do not differ substantially from the default inversion results and velocities at depth are also underestimated by the inversion with structural constraints.

The black lines in Fig. 7 illustrate the results of the constrained inversion based on initial models with constant layer velocities (constrained initial models). Our results demonstrate that constrained initial models permit to accurately estimate the velocity structure of the synthetic models and to precisely resolve the interface depths. Moreover, in case of conceptual model F2, the incorporation of complementary data in the inversion permits to detect the velocity reversal between the snow cover and the underlying debris layer. 
The Cryosphere Discuss., https://doi.org/10.5194/tc-2019-52

Manuscript under review for journal The Cryosphere

Discussion started: 27 March 2019

(c) Author(s) 2019. CC BY 4.0 License.

\section{(c) (1)}
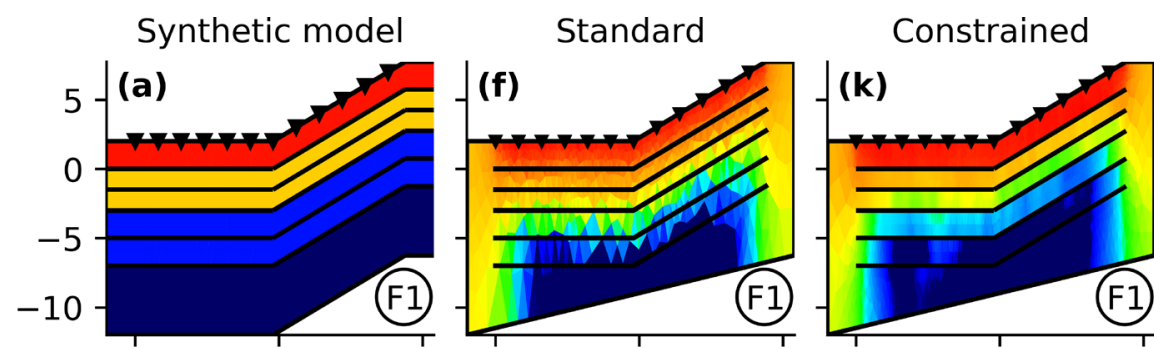

Extended constrained
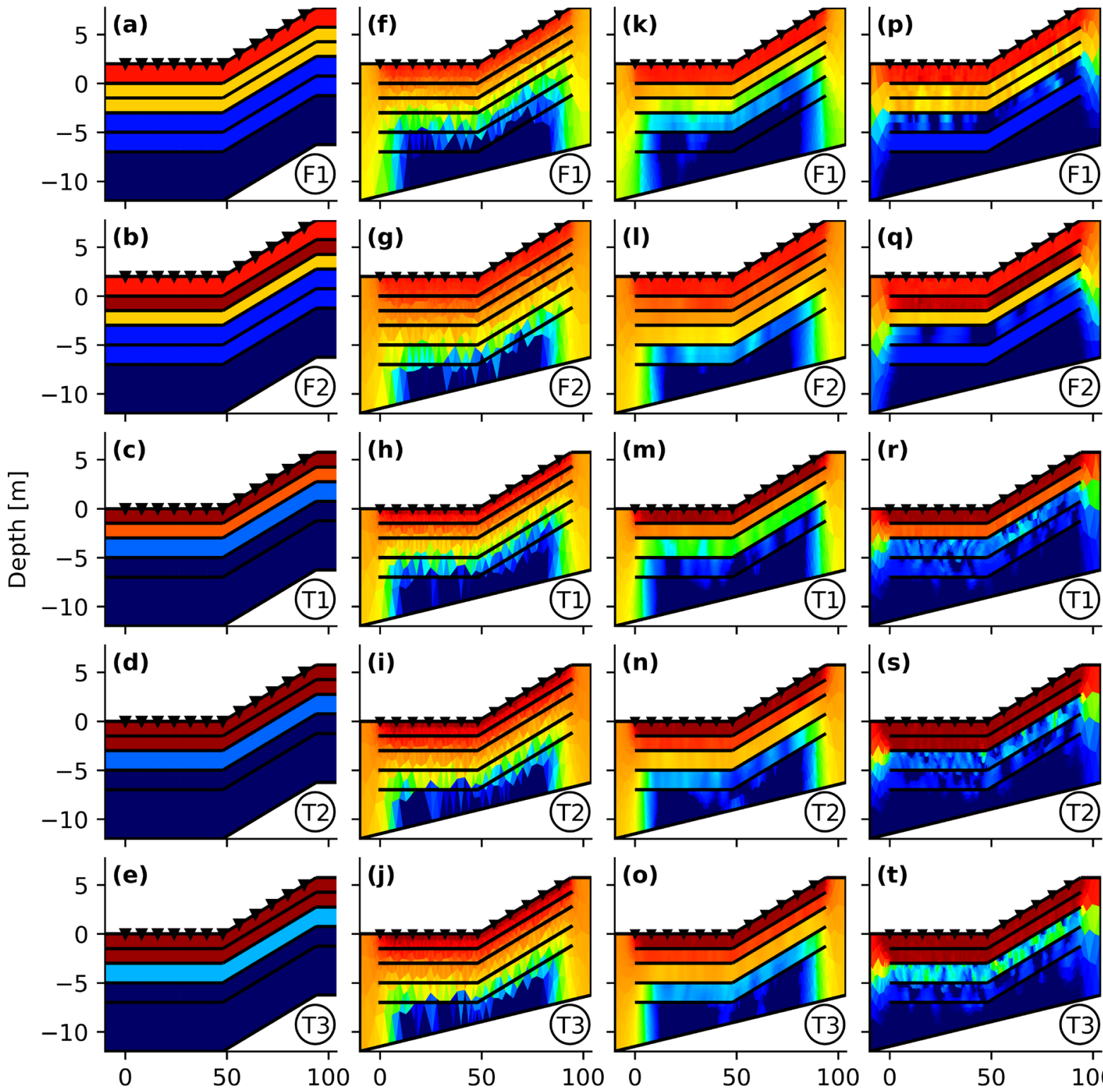

(o)

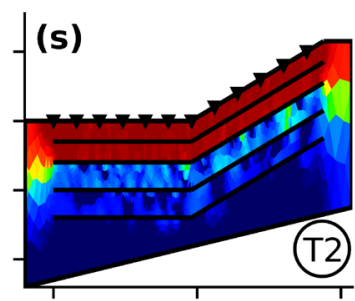

\section{Distance $[\mathrm{m}]$}

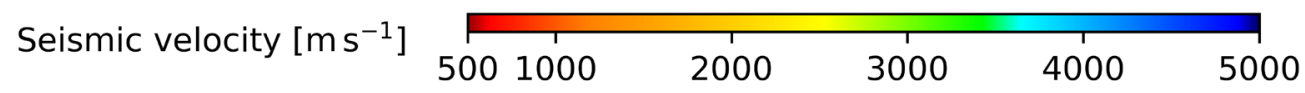

Figure 6: Numerical models (a)-(e) with the imaging results obtained following different inversion approaches: standard inversion with gradient initial model $(\mathrm{f})-(\mathrm{j})$; constrained inversion with gradient initial model $(\mathrm{k})-(\mathrm{o})$; extended constrained inversion with constrained initial model (p)-(t). 
The Cryosphere Discuss., https://doi.org/10.5194/tc-2019-52

Manuscript under review for journal The Cryosphere

Discussion started: 27 March 2019

(c) Author(s) 2019. CC BY 4.0 License.
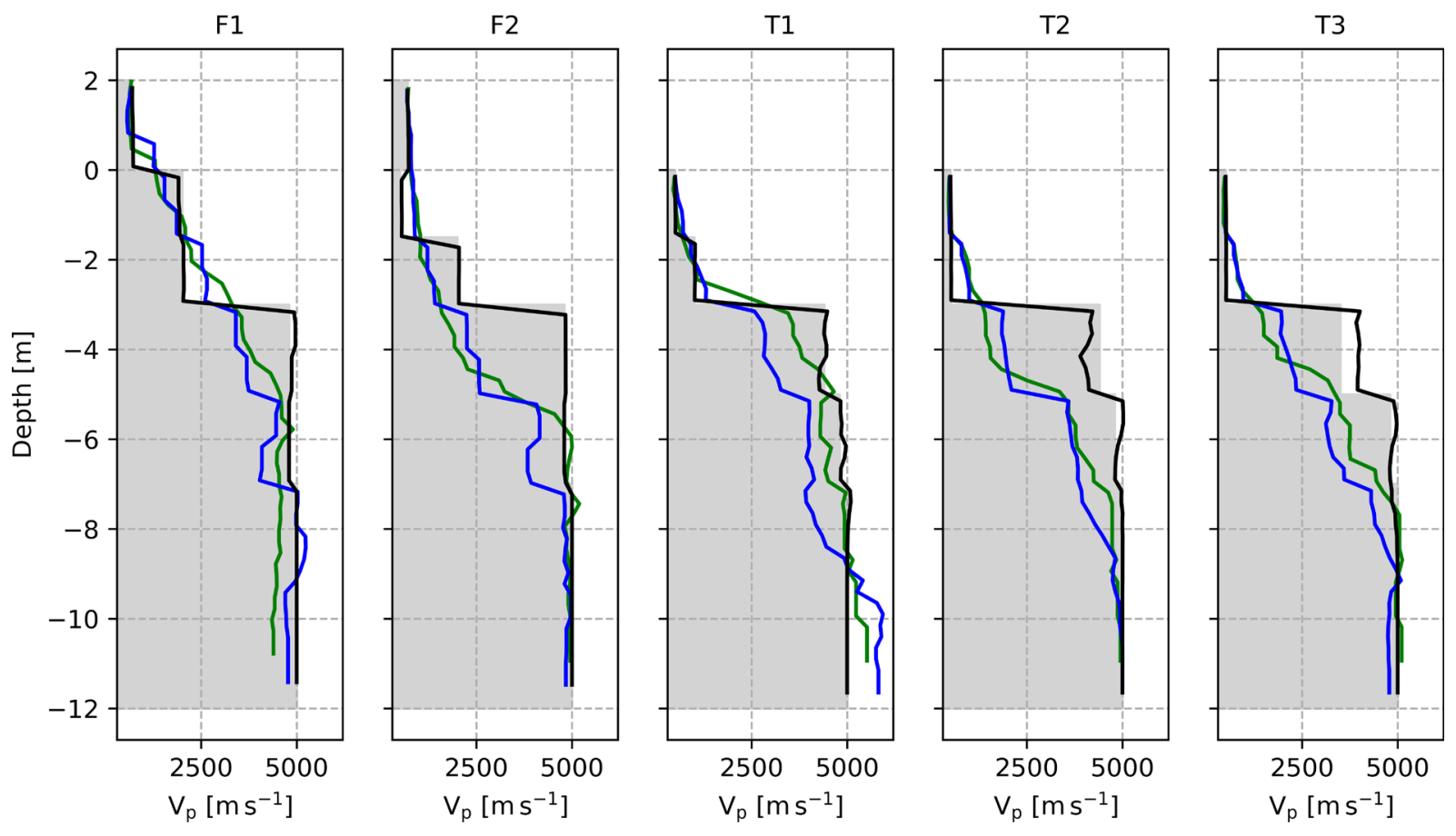

Standard

Constrained

Extended constrained

Synthetic model

Figure 7: Numerical evaluation of the performance of the standard inversion using a gradient initial model (green), the constrained inversion using a gradient initial model (blue) and the extended constrained inversion based on a constrained initial model (black). The gray area illustrates the velocity structure of the synthetic models.

Based on conceptual model F2 we investigate the sensitivity of the extended constrained inversion approach to erroneous initial models. Therefore, we separately alter the initial velocity of each layer by $\pm 20 \%$ and $\pm 50 \%$ resulting in 24 initial models. To enhance the interpretability of the inversion results, we convert the 2D tomography to averaged 1D velocity curves as presented in Fig. 8. As reference, the black lines illustrate the result based on the correct initial model (presented in Fig. 7). In general, the influence of an erroneous initial model is negligible in the near surface layer (up to $4 \mathrm{~m}$ depth), whereas the estimated velocities at depth are more sensitive to errors in the initial layer velocities. In case of changing the initial layer velocity by $\pm 20 \%$ the constrained inversion is still able to estimate physically plausible seismic velocities corresponding to the velocity structure of the synthetic model. Changes in the initial layer velocities of $\pm 50 \%$ reveal that the inversion results are less affected by the absolute errors, but instead are more sensitive to velocity contrasts caused by the erroneous initial layer velocities. However, our results demonstrate that applying an extended constrained 
The Cryosphere Discuss., https://doi.org/10.5194/tc-2019-52

Manuscript under review for journal The Cryosphere

Discussion started: 27 March 2019

(c) Author(s) 2019. CC BY 4.0 License.

inversion approach helps to confine the influence of incorrect initial models on the estimated velocities to the affected layer.
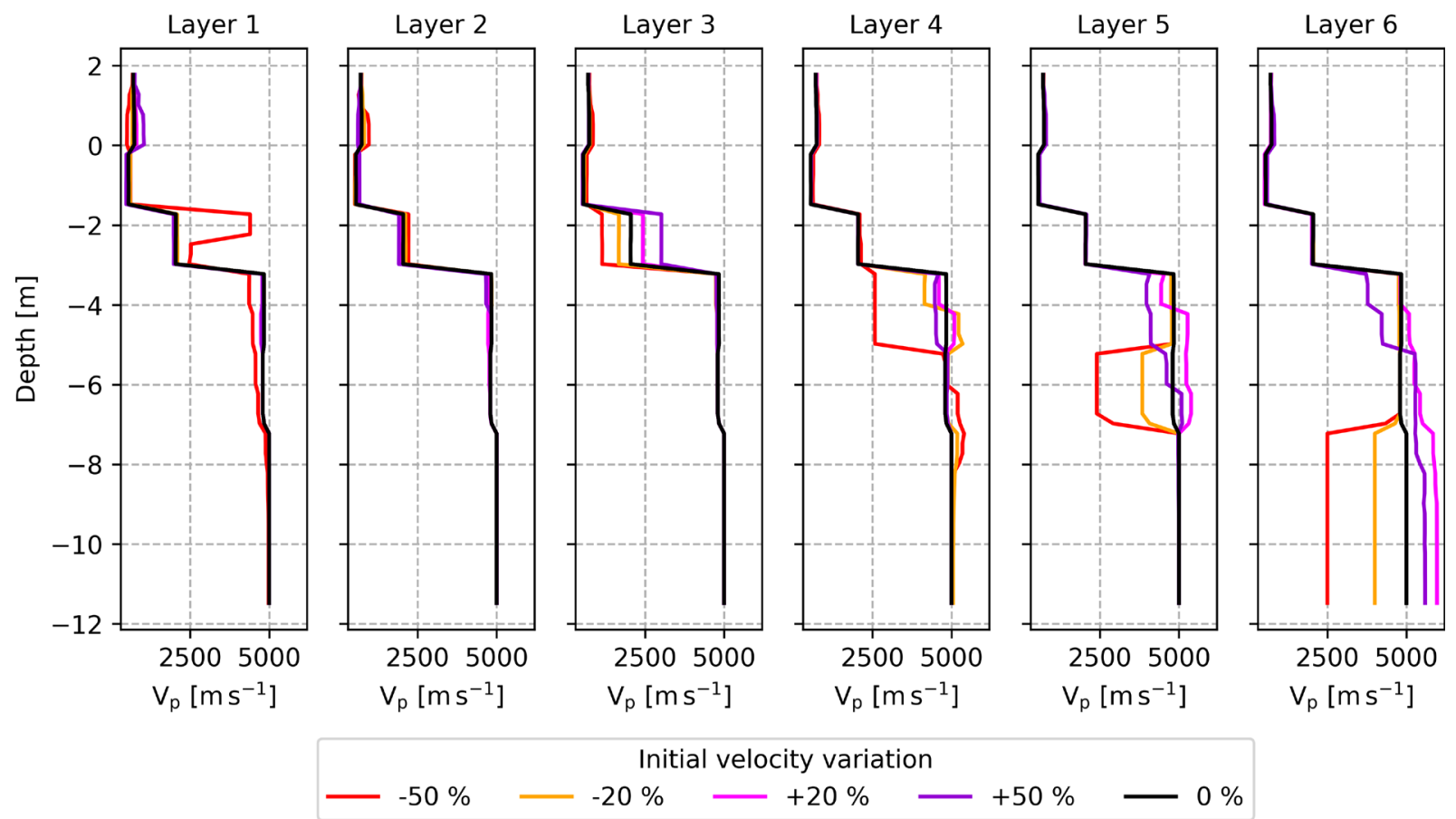

5 Figure 8: Influence of erroneous initial layer velocities on the models resolved by the extended constrained inversion separately evaluated for each layer of conceptual model F2.

\subsection{Field study}

To evaluate the applicability of the constrained inversion for real seismic data and the influence of constant initial layer velocities, we use the refraction seismic data set acquired on 17 May 2017 at Hoher Sonnblick summit. For seismic data processing and picking of first break travel times we use the SeisSpace ProMAX seismic processing software. For the inversion of the first break travel times we consider three different inversion approaches: (1) standard inversion based on a gradient initial model, (2) constrained inversion using a gradient initial model, and (3) extended constrained inversion based on a constrained initial model. The initial models used for the inversions mainly rely on information from geological maps and the structural information and bulk electrical properties obtained from the modeling of GPR signatures. The regularization parameter $(\lambda)$ and relative horizontal smoothing (zWeight) used for each inversion approach are summarized in Table 2. 
The Cryosphere Discuss., https://doi.org/10.5194/tc-2019-52

Manuscript under review for journal The Cryosphere

Discussion started: 27 March 2019

(c) Author(s) 2019. CC BY 4.0 License.

Table 2. Inversion parameters $(\lambda, z W e i g h t)$ and convergence parameters (\# iterations, RMS, $\left.\chi^{2}\right)$ for the different applied inversion approaches

\begin{tabular}{lccccc}
\hline & $\lambda$ & zWeight & \# iterations & RMS [s] & $\chi^{2}$ \\
\hline Standard inversion & 30 & 0.75 & 3 & $0.8 \mathrm{e}-3$ & 0.60 \\
Constrained inversion & 30 & 0.75 & 3 & $0.8 \mathrm{e}-3$ & 0.68 \\
Extended constrained inversion & 2 & 0.5 & 3 & $0.9 \mathrm{e}-3$ & 0.78 \\
\hline
\end{tabular}

Figure 9a illustrates the result obtained by means of standard inversion based on a gradient initial model defined 5 by a minimum velocity of $700 \mathrm{~ms}^{-1}$ at the surface and a maximum velocity of $5000 \mathrm{~ms}^{-1}$ at the bottom of the model. Although the standard approach resolves the strong velocity contrast between the snow cover and the frozen compacted rocks at depth, the distinctive interface between the snow cover and the underlying debris layer as detected in the GPR data cannot be delineated. Furthermore, considering the GPR-based depth of the debris-bedrock interface, we observed a possible underestimation of the seismic velocities, in accordance with the synthetic data simulations presented above. Hence, we incorporate the GPR-derived structural information as constraints in the inversion and based on a gradient initial model we obtain the result shown in Fig. 9b. The constrained inversion permits to delineate a near-surface low velocity layer $\left(\mathrm{V}_{\mathrm{p}}<1000 \mathrm{~ms}^{-1}\right)$. Underneath we resolved a layer characterized by seismic velocities of approximately $2000 \mathrm{~ms}^{-1}$ and obtained higher seismic velocities of around $3000 \mathrm{~ms}^{-1}$ below this intermediate layer. Within the deepest layer seismic velocities of up to more than $5000 \mathrm{~ms}^{-1}$ were resolved. To further refine the inversion results we create an initial model consisting of three layers with constant seismic velocities of $700 \mathrm{~ms}^{-1}$ (corresponding to compacted snow) in the top layer, $1000 \mathrm{~ms}^{-1}$ (associated to the expected frozen saturated debris) in the second layer and $5000 \mathrm{~ms}^{-1}$ in the bottom layer (representing the bedrock). Inverting the data based on this constrained initial model yields the result presented in Fig. 9c. Regarding the top and the intermediate layer, we obtain velocities similar to the inversion result shown in Fig. 9b; yet, constraining the initial layer velocities permits to better resolve the strong velocity contrast between the top and the intermediate layers. Furthermore, at greater depths the usage of the constrained initial model helps to solve for the seismic contact at the location of the interface indicated by the GPR data. Our results reveal, that the extended constrained RST inversion based on constant initial layer velocities permits to solve for a model more consistent with the one solved for GPR data. Moreover, our approach permitted to resolve a three-layer model with an almost uniform velocity structure within each layer. 
The Cryosphere Discuss., https://doi.org/10.5194/tc-2019-52

Manuscript under review for journal The Cryosphere

Discussion started: 27 March 2019

(c) Author(s) 2019. CC BY 4.0 License.

(c) (i)
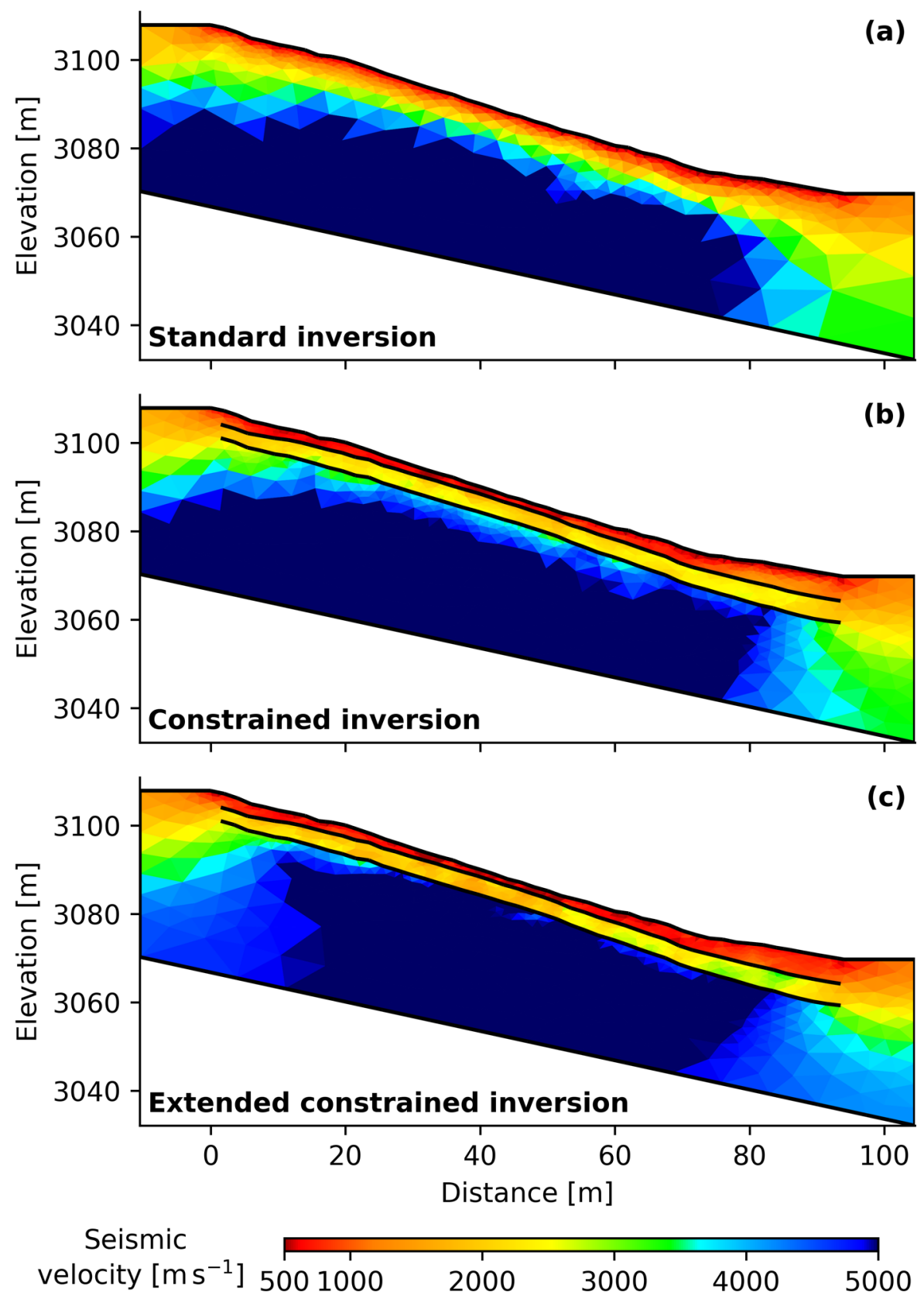

Figure 9: Inversion results for real seismic data measured at Hoher Sonnblick obtained by (a) standard inversion using a gradient initial model, (b) constrained inversion using a gradient initial model, and (c) extended constrained inversion based on a constrained initial model. 
The Cryosphere Discuss., https://doi.org/10.5194/tc-2019-52

Manuscript under review for journal The Cryosphere

Discussion started: 27 March 2019

(c) Author(s) 2019. CC BY 4.0 License.

The quantitative interpretation of the inversion results requires taking into account the data-misfit of the different inversion approaches (convergence parameters summarized in Table 2). While for each approach the inversion of the data takes three iterations to reach the data fit criterion $\left(\chi^{2}\right.$ misfit $\left.\leq 1\right)$, the values of the RMS and the $\chi^{2}$ misfits increase when constraints are imposed on the inversion. However, even for the extended constrained

5 inversion approach (structural constraints and a constrained initial model) we obtain a $\chi^{2}$ value lower than 1 and an RMS of less than $1 \mathrm{~ms}$ indicating an adequate data fit. Hence, we use the inversion result shown in Fig. 9c for the interpretation of the site permafrost investigation. Here, seismic velocities around $800 \mathrm{~ms}^{-1}$ in the top layer correspond to the compacted snow cover delineated by GPR investigations. In the lower part of the profile (starting at $70 \mathrm{~m}$ ), the thickness of this layer increases and we observed higher seismic velocities at the base of

10 the snow cover most likely related to firn deposited in this area of Hoher Sonnblick summit. By incorporating the GPR-based constraints, a clear boundary between the snow cover and the subjacent geological media can be delineated. For the second layer we resolve seismic velocities of approximately $2000 \mathrm{~ms}^{-1}$ with areas reaching up to $3000 \mathrm{~ms}^{-1}$. This velocity structure indicates a complex layer consisting of frozen debris with ice-filled voids and frozen saturated fractured rock, which is in agreement with the results presented in Schöner et al. (2012a).

15 The bottom layer is characterized by seismic velocities of around $5000 \mathrm{~ms}^{-1}$ corresponding to the granite gneiss bedrock as also observed by Schöner et al. (2012a). However, we observe lower seismic velocities $\left(\mathrm{V}_{\mathrm{p}} \sim 3500\right.$ $\mathrm{ms}^{-1}$ ) within this layer in the upper part of the profile ( 0 to $20 \mathrm{~m}$ ). Located in the vicinity of the Sonnblick Observatory, this anomaly can be attributed to the artificial structures of the external entrance area of the building (e.g. staircase).

\section{Conclusions}

In this study, we presented a revision of the literature regarding seismic velocities in alpine permafrost (for laboratory and field experiments). Based on this revision we proposed a series of conceptual models and their corresponding seismic velocities illustrating different conditions in a permafrost environment. In a second step, we investigated the possibility to improve the quantitative inversion of refraction seismic data through the incorporation of complementary data permitting (1) the constrained inversion based on a gradient initial model and (2) the extended constrained inversion based on a constrained initial model with constant layer velocities. Using the proposed conceptual models, we conducted a detailed numerical study to evaluate the performance of the standard, the constrained and the extended constrained inversion approach. Our results demonstrate the potential of the extended constrained inversion to resolve the shortcomings of the standard inversion, namely, the 30 underestimation of seismic velocities and the imperfect layer boundary delineation. Furthermore, we investigated 
The Cryosphere Discuss., https://doi.org/10.5194/tc-2019-52

Manuscript under review for journal The Cryosphere

Discussion started: 27 March 2019

(c) Author(s) 2019. CC BY 4.0 License.

the sensitivity of the extended constrained inversion to erroneous initial models. For this purpose, the initial velocity of each layer was distorted individually while those of the other layers were held constant. Thus, we were thereby able to show the robustness of the extended constrained inversion in case of errors in the initial model.

5 Besides the numerical study, we presented the successful application of the extended constrained inversion on a real seismic data set acquired at the Hoher Sonnblick summit. We showed that a collocated GPR data set provides sufficient information to constrain the inversion of the seismic refraction data. Our results permitted to resolve (1) a snow cover with varying thickness along the profile, (2) a layer consisting of debris and fractured rocks with ice-filled voids, and (3) a deep-seated granite gneiss bedrock layer at the bottom, which is in

10 accordance with the results from a previous study.

The results in this study suggest that the presented extended constrained inversion approach could help to obtain enhanced subsurface images, especially for alpine areas, where, for example, no borehole data are available or electrical data cannot be acquired due to bad galvanic contact between the electrodes and the ground. Hence, we believe that data from other electromagnetic geophysical methods, such as low-induction number and transient

15 electromagnetic induction, could also be valuable supplements to refraction seismic data in the context of multimethod permafrost characterization. 
The Cryosphere Discuss., https://doi.org/10.5194/tc-2019-52

Manuscript under review for journal The Cryosphere

Discussion started: 27 March 2019

(c) Author(s) 2019. CC BY 4.0 License.

(c) (i)

\section{Code and data availability}

Datasets and code used within the current study are available from the corresponding author on reasonable request.

\section{Team list}

5 Matthias Steiner, Florian M. Wagner, Adrian Flores Orozco

\section{Author contribution}

All authors contributed equally to the preparation of this manuscript

\section{Competing interests}

The authors declare that they have no conflict of interest.

\section{Acknowledgements}

The preparation of this material is supported through the Austrian Academy of Sciences (OeAW) research project ATMOperm. We also want to thank Theresa Maierhofer, Martin Mayr, Walter Loderer, Stefan Reisenhofer and Jakob Gallistl for their help during the fieldwork. 
The Cryosphere Discuss., https://doi.org/10.5194/tc-2019-52

Manuscript under review for journal The Cryosphere

Discussion started: 27 March 2019

(c) Author(s) 2019. CC BY 4.0 License.

\section{References}

Beniston, M., Farinotti, D., Stoffel, M., Andreassen, L. M., Coppola, E., Eckert, N., Fantini, A., Giacona, F., Hauck, C., Huss, M., Huwald, H., Lehning, M., López-Moreno, J., Magnusson, J., Marty, C., Morán-Tejéda, E., Morin, S., Naaim, M., Provenzale, A., Rabatel, A., Six, D., Stötter, J., Strasser, U., Terzago, S., and Vencent, C.:

5 The European mountain cryosphere: a review of its current state, trends, and future challenges, The Cryosphere, 12, 759-794, https://doi.org/10.5194/tc-12-759-2018, 2018.

Bergmann, P., Ivandic, M., Norden, B., Rücker, C., Kiessling, D., Lüth, S., Schmidt-Hattenberger, C., and Juhlin, C.: Combination of seismic reflection and constrained resistivity inversion with an application to 4D

10 imaging of the $\mathrm{CO}_{2}$ storage site, Ketzin, Germany, Geophysics, 79(2), B37-B50, https://doi.org/10.1190/GEO2013-0131.1, 2014.

Berthling, I., Etzelmüller, B., Farbrot, H., Isaksen, K., Wåle, M., and Ødegård, R.: GPR soundings of rock glaciers on Svalbard, in: Applied geophysics in periglacial environments, edited by: Hauck, C., and Kneisel, C., Cambridge University Press, Cambridge, United Kingdom, 172-177, https://doi.org/10.1017/CBO9780511535628.013, 2008.

Biskaborn, B. K. , Lanckman, J. P. , Lantuit, H. , Elger, K. , Dmitry, S. , William, C. and Vladimir, R.: The new database of the Global Terrestrial Network for Permafrost (GTN-P), Earth Syst. Sci. Data, 7, 245-259, https://doi.org/10.5194/essd-7-245-2015, 2015.

Bommer, C., Phillips, M. and Arenson, L. U.: Practical recommendations for planning, constructing and maintaining infrastructure in mountain permafrost, Permafrost Periglac., 21(1), 97-104, https://doi.org/10.1002/ppp.679, 2010.

Böhm, R., Auer, I., Schöner, W. (Eds.): Labor über den Wolken - Die Geschichte des SonnblickObservatoriums, Böhlau Verlag, Wien, Austria, 2011.

Coe, J. A., Bessette-Kirton, E. K., and Geertsema, M.: Increasing rock-avalanche size and mobility in Glacier 30 Bay National Park and Preserve, Alaska detected from 1984 to 2016 Landsat imagery, Landslides, 15, 393-407, https://doi.org/10.1007/s10346-017-0879-7, 2018. 
The Cryosphere Discuss., https://doi.org/10.5194/tc-2019-52

Manuscript under review for journal The Cryosphere

Discussion started: 27 March 2019

(c) Author(s) 2019. CC BY 4.0 License.

Deline P., Broccolato M., Noetzli J., Ravanel L., and Tamburini A.: The December 2008 Crammont Rock Avalanche, Mont Blanc Massif Area, Italy, in: Landslide Science and Practice, edited by: Margottini, C., Canuti, P., and Sassa, K., Springer, Berlin, Heidelberg, Germany, 403-408, https://doi.org/10.1007/978-3-642-31337$\underline{0 \quad 52}, 2013$.

5

Doetsch, J., Linde, N., Pessognelli, M., Green, A. G., and Günther, T.: Constraining 3-D electrical resistance tomography with GPR reflection data for improved aquifer characterization. J. Appl. Geophysics, 78, 68-76, https://doi.org/10.1016/j.jappgeo.2011.04.008, 2012.

10 Draebing, D.: Application of refraction seismics in alpine permafrost studies: A review. Earth-science reviews, 155, 136-152, https://doi.org/10.1016/j.earscirev.2016.02.006, 2016.

Draebing, D., and Krautblatter, M.: P-wave velocity changes in freezing hard low-porosity rocks: a laboratorybased time-average model. The Cryosphere, 6(5), 1163-1174, https://doi.org/10.5194/tc-6-1163-2012, 2012.

15

Exner, C.: Geologische Karte der Sonnblickgruppe, Geol. Surv. of Austria, 1962.

Exner, C.: Erläuterungen zur geologischen Karte der Sonnblickgruppe 1: 50000, Geol. Surv. of Austria, 1964.

20 Gallardo, L. A., and Meju, M. A.: Characterization of heterogeneous near-surface materials by joint 2D inversion of $\mathrm{dc}$ resistivity and seismic data, Geophys. Res. Letters, 30(13), 1658, https://doi.org/10.1029/2003GL017370, 2003.

Gobiet, A., Kotlarski, S., Beniston, M., Heinrich, G., Rajczak, J., and Stoffel, M.: 21 st century climate change in 25 the European Alps-a review, Sci. Total Environ., 493, 1138-1151, https://doi.org/10.1016/j.scitotenv.2013.07.050, 2014.

Günther, T. and Rücker, C.: Boundless Electrical Resistivity Tomography BERT 2-the user tutorial. http://www.resistivity.net, last access: 15 February 2019, 2017. 
The Cryosphere Discuss., https://doi.org/10.5194/tc-2019-52

Manuscript under review for journal The Cryosphere

Discussion started: 27 March 2019

(c) Author(s) 2019. CC BY 4.0 License.

Günther, T., Rücker, C. and Spitzer, K.: Three-dimensional modeling and inversion of DC resistivity data incorporating topography-II. Inversion, Geophys. J. Int., 166, 506-517, https://doi.org/10.1111/j.1365246X.2006.03011.x, 2006.

5 Haeberli, W., Noetzli, J., Arenson, L., Delaloye, R., Gärtner-Roer, I., Gruber, S., Isaksen, K., Kneisl, C., Krautblatter, M., and Phillips, M.: Mountain permafrost: development and challenges of a young research field, J. Glaciol., 56(200), 1043-1058, https://doi.org/10.3189/002214311796406121, 2010.

Haeberli, W., Schaub, Y., and Huggel, C.: Increasing risks related to landslides from degrading permafrost into new lakes in de-glaciating mountain ranges, Geomorphology, 293, 405-417, https://doi.org/10.1016/j.geomorph.2016.02.009, 2016.

Harris, C., Arenson, L. U., Christiansen, H. H., Etzelmüller, B., Frauenfelder, R., Gruber, S., Haeberli, W., Hauck, C., Hölzle, M., Humlum, O., Isaksen, K., Kääb, A., Kern-Lütschg, M. A., Lehning, M., Matsuoka, N., 15 Murton, J. B., Nötzli, J., Phillips, M., Ross, N., Seppälä, M., Springman, S. M., and Vonder Mühll, D.: Permafrost and climate in Europe: Monitoring and modeling thermal, geomorphological and geotechnical responses, Earth-Sci. Rev., 92(3-4), 117-171, https://doi.org/10.1016/j.earscirev.2008.12.002, 2009.

Harris, S. A., French, H. M., Heginbottom, J. A., Johnston, G. H., Ladanyi, B., Sego, D. C., and van Everdingen,

20 R. O.: Glossary of permafrost and related ground-ice terms, Associate Committee on Geotechnical Research, National Research Council of Canada, Ottawa, 1988.

Hauck, C.: New concepts in geophysical surveying and data interpretation for permafrost terrain. Permafrost Periglac., 24(2), 131-137, https://doi.org/10.1002/ppp.1774, 2013.

Hauck, C., Böttcher, M., and Maurer, H.: A new model for estimating subsurface ice content based on combined electrical and seismic data sets, The Cryosphere, 5(2), 453-468, https://doi.org/10.5194/tc-5-453-2011, 2011.

Hauck, C., Isaksen, K., Vonder Mühll, D., and Sollid, J. L.: Geophysical surveys designed to delineate the 30 altitudinal limit of mountain permafrost: an example from Jotunheimen, Norway, Permafrost Periglac., 15(3), 191-205, https://doi.org/10.1002/ppp.493, 2004. 
The Cryosphere Discuss., https://doi.org/10.5194/tc-2019-52

Manuscript under review for journal The Cryosphere

Discussion started: 27 March 2019

(c) Author(s) 2019. CC BY 4.0 License.

Hausmann, H., Krainer, K., Brückl, E., and Mostler, W.: Internal structure and ice content of Reichenkar rock glacier (Stubai Alps, Austria) assessed by geophysical investigations, Permafrost Periglac., 18(4), 351-367, https://doi.org/10.1002/ppp.601, 2007.

5 Hellman, K., Ronczka, M., Günther, T., Wennermark, M., Rücker, C., and Dahlin, T.: Structurally coupled inversion of ERT and refraction seismic data combined with cluster-based model integration, J. of Appl. Geophys., 143, 169-181, https://doi.org/10.1016/j.jappgeo.2017.06.008, 2017.

Hilbich, C.: Time-lapse refraction seismic tomography for the detection of ground ice degradation, The 10 Cryosphere, 4(3), 243, https://doi.org/10.5194/tc-4-243-2010, 2010.

Hilbich, C., Hauck, C., Hoelzle, M., Scherler, M., Schudel, L., Völksch, I., Vonder Mühll, D., and Mäusbacher, R.: Monitoring mountain permafrost evolution using electrical resistivity tomography: A 7-year study of seasonal, annual, and long-term variations at Schilthorn, Swiss Alps, J. Geophys. Res-Earth, 113(F01S90), 15 https://doi.org/10.1029/2007JF000799, 2008.

Hilbich, C., Marescot, L., Hauck, C., Loke, M. H., and Mäusbacher, R.: Applicability of electrical resistivity tomography monitoring to coarse blocky and ice-rich permafrost landforms. Permafrost Periglac., 20(3), 269284, https://doi.org/10.1002/ppp.652, 2009.

20

Hinkel, K. M., Doolittle, J. A., Bockheim, J. G., Nelson, F. E., Paetzold, R., Kimble, J. M., and Travis, R.: Detection of subsurface permafrost features with ground-penetrating radar, Barrow, Alaska, Permafrost Periglac., 12(2), 179-190, https://doi.org/10.1002/ppp.369, 2001.

25 Keiler, M., Knight, J., and Harrison, S.: Climate change and geomorphological hazards in the eastern European Alps, Philos. T. Roy. Soc. A, 368(1919), 2461-2479, https://doi.org/10.1098/rsta.2010.0047, 2010.

Kellerer-Pirklbauer, A. and Kaufmann, V.: Deglaciation and its impact on permafrost and rock glacier evolution: New insight from two adjacent cirques in Austria, Sci. Total Environ., 621, 1397-1414, 30 https://doi.org/10.1016/j.scitotenv.2017.10.087, 2017. 
The Cryosphere Discuss., https://doi.org/10.5194/tc-2019-52

Manuscript under review for journal The Cryosphere

Discussion started: 27 March 2019

(c) Author(s) 2019. CC BY 4.0 License.

Keuschnig, M., Krautblatter, M., Hartmeyer, I., Fuss, C., and Schrott, L.: Automated electrical resistivity tomography testing for early warning in unstable permafrost rock walls around alpine infrastructure, Permafrost Periglac., 28(1), 158-171, https://doi.org/10.1002/ppp.1916, 2017.

5 Kneisel, C., Emmert, A., and Kästl, J.: Application of 3D electrical resistivity imaging for mapping frozen ground conditions exemplified by three case studies, Geomorphology, 210, 71-82, https://doi.org/10.1016/j.geomorph.2013.12.022, 2014.

Krautblatter, M., Verleysdonk, S., Flores-Orozco, A., and Kemna, A.: Temperature-calibrated imaging of

10 seasonal changes in permafrost rock walls by quantitative electrical resistivity tomography (Zugspitze, German/Austrian Alps), J. Geophys. Res-Earth., 115(F2), https://doi.org/10.1029/2008JF001209, 2010.

Linde, N., Tryggvason, A., Peterson, J. E., and Hubbard, S. S.: Joint inversion of crosshole radar and seismic traveltimes acquired at the South Oyster Bacterial Transport Site, Geophysics, 73(4), G29-G37, 15 https://doi.org/10.1190/1.2937467, 2008.

Maierhofer, T., Steiner, M., Chwatal, W., Schöner, W., and Flores Orozco, A.: Modeling of ground penetrating radar in alpine permafrost at Hoher Sonnblick summit, in: 5th European Conference on Permafrost, Book of Abstract, edited by: Deline, P., Bodin, X., and Ravanel, L., Chamonix-Montblanc, France, 23 June-1 July 2018, $20 \quad 978-979,2018$.

Marshall, S. J.: The cryosphere, Princeton University Press, Princeton, New Jersey, USA, 2011.

Noetzli, J. and Gruber, S.: Transient thermal effects in Alpine permafrost, The Cryosphere, 3(1), 85-99, https://doi.org/10.5194/tc-3-85-2009, 2009.

Nur, A. and Simmons, G.: The effect of saturation on velocity in low porosity rocks, Earth Planet. Sc. Lett., 7(2), 183-193, https://doi.org/10.1016/0012-821X(69)90035-1, 1969.

30 PERMOS: Permafrost in Switzerland 2010/2011 to 2013/2014, Glaciological Report Permafrost No. 12-15 of the Cryospheric Commission of the Swiss Academy of Sciences, edited by: Noetzli, J., Luethi, R., and Staub, B., 85 pp, 2016. 
The Cryosphere Discuss., https://doi.org/10.5194/tc-2019-52

Manuscript under review for journal The Cryosphere

Discussion started: 27 March 2019

(c) Author(s) 2019. CC BY 4.0 License.

Phillips, M., Wolter, A., Lüthi, R., Amann, F., Kenner, R., and Bühler, Y.: Rock slope failure in a recently deglaciated permafrost rock wall at Piz Kesch (Eastern Swiss Alps), February 2014, Earth Surf. Proc. Land., 42(3), 426-438, https://doi.org/10.1002/esp.3992, 2017.

5 Ravanel, L., Magnin, F., and Deline, P.: Impacts of the 2003 and 2015 summer heatwaves on permafrostaffected rock-walls in the Mont Blanc massif, Sci. Total Environ., 609, 132-143, https://doi.org/10.1016/j.scitotenv.2017.07.055, 2017.

Reynolds, J. M.: An introduction to applied and environmental geophysics. John Wiley \& Sons, Hoboken, New 10 Jersey, USA, 2011.

Rogger, M., Chirico, G. B., Hausmann, H., Krainer, K., Brückl, E., Stadler, P., and Blöschl, G.: Impact of mountain permafrost on flow path and runoff response in a high alpine catchment, Water Resour. Res., 53(2), 1288-1308, https://doi.org/10.1002/2016WR019341, 2017.

15

Ronczka, M., Hellman, K., Günther, T., Wisén, R., and Dahlin, T.: Electric resistivity and seismic refraction tomography: a challenging joint underwater survey at Äspö Hard Rock Laboratory, Solid Earth, 8(3), 671-682, https://doi.org/10.5194/se-8-671-2017, 2017.

20 Rücker, C., Günther, T., and Wagner, F. M.: pyGIMLi: An open-source library for modeling and inversion in geophysics, Comput. Geosci., 109, 106-123, https://doi.org/10.1016/j.cageo.2017.07.011, 2017.

Schöner, W., Boeckli, L., Hausmann, H., Otto, J. C., Reisenhofer, S., Riedl, C., and Seren, S.: Spatial patterns of permafrost at Hoher Sonnblick (Austrian Alps)-extensive field-measurements and modeling approaches,

25 Austrian J. Earth Sci., 105(2), 154-168, 2012a.

Schöner, W., Böhm, R., and Auer, I.: 125 years of high-mountain research at Sonnblick Observatory (Austrian Alps)_from "the house above the clouds" to a unique research platform, Theor. Appl. Climatol., 110(4), 491498, https://doi.org/10.1007/s00704-012-0689-8, 2012 b. 
The Cryosphere Discuss., https://doi.org/10.5194/tc-2019-52

Manuscript under review for journal The Cryosphere

Discussion started: 27 March 2019

(c) Author(s) 2019. CC BY 4.0 License.

Stiegler, C., Rode, M., Sass, O., and Otto, J. C.: An undercooled scree slope detected by geophysical investigations in sporadic permafrost below 1000 m ASL, central Austria, Permafrost Periglac., 25(3), 194-207, https://doi.org/10.1002/ppp.1813, 2014.

5 Supper, R., Ottowitz, D., Jochum, B., Römer, A., Pfeiler, S., Kauer, S., Keuschnigg, M., and Ita, A.: Geoelectrical monitoring of frozen ground and permafrost in alpine areas: field studies and considerations towards an improved measuring technology. Near Surf. Geophys., 12(1), 93-115, https://doi.org/10.3997/1873$\underline{0604.2013057}, 2014$.

10 Travelletti, J., Malet, J. P., Hibert, C., and Grandjean, G.: Integration of geomorphological, geophysical and geotechnical data to define the 3D morpho-structure of the La Valette mudslide (Ubaye Valley, French Alps), in: Proceedings of the International Conference on Landslide Processes: from geomorphologic mapping to dynamic modeling, Strasbourg, France, 6-7 February 2009, 203-208, 2009. 